\title{
Hereditary caeruloplasmin deficiency: clinicopathological study of a patient
}

\author{
T Kawanami, T Kato, M Daimon, M Tominaga, H Sasaki, K Maeda, S Arai, Y Shikama, \\ T Katagiri
}

\begin{abstract}
A 58 year old patient with dementia, oral dyskinesia, and diabetes mellitus is described. He had an undetectable concentration of serum caeruloplasmin, as an autosomal recessive trait. Brain MRI disclosed a pronounced hypointensity in the bilateral putamina, caudate, and dentate nuclei on both $T 1$ and $T 2$ weighted images. Pathological findings were mainly in those regions of the brain and consisted of neuronal cell loss with gliosis, heavy iron deposition, and spheroids. Visceral organs also had iron deposition, especially severe in the liver and pancreas. The present patient and other recorded cases constitute a clinicopathological entity of hereditary caeruloplasmin deficiency, different from Wilson's disease.
\end{abstract}

(F Neurol Neurosurg Psychiatry 1996;61:506-509)

Keywords: hereditary caeruloplasmin deficiency; dementia; diabetes mellitus; iron deposition

Third Department of Internal Medicine, Yamagata University School of Medicine, Yamagata, Japan

T Kawanami

T Kato

M Daimon

M Tominaga

H Sasaki

Department of

Pathology, Yamagata

University School of

Medicine, Yamagata,

Japan

K Maeda

$S$ Arai

Department of

Internal Medicine

Yamagata Prefectural

Kahoku Hospital,

Yamagata, Japan

Y Shikama

T Katagiri

Correspondence to:

Dr Toru Kawanami, Third

Department of Internal

Medicine, Yamagata

University School of

Medicine, 2-2-2, Iida-Nishi

Yamagata, 990-23, Japan.

Received 22 November 1995

and in final revised form

3 April 1996

Accepted 26 April 1996
Hereditary caeruloplasmin deficiency is a newly recognised disorder first described by Miyajima et al in 1987.' At the present time, there are three reports ${ }^{1-3}$ on the disease. The patients had neurological and systemic symptoms such as dementia, involuntary movements, and diabetes. Iron deposition in the brain and liver is a feature of the disorder as well as serum caeruloplasmin deficiency. Caeruloplasmin deficiency in those patients is an autosomal recessive phenotype and recent investigations $^{45}$ showed mutations of the caeruloplasmin gene on chromosome $3 \mathrm{q}$ that differ from the Wilson's disease gene, which is localised on chromosome $13 \mathrm{q}^{6}$ and the hereditary haemochromatosis gene localised to chromosome $6 \mathrm{p} .{ }^{7}$ Nielson et $a l^{8}$ reported a case of hereditary haemochromatosis with iron accumulation in the basal ganglia and cerebellum. This pattern of iron deposition in the brain is so similar to hereditary caeruloplasmin deficiency that the question arises as to what differences exist between those disorders.

We report a necropsy of a patient with hereditary caeruloplasmin deficiency with a mutation of the caeruloplasmin gene. ${ }^{9}$ Our clinicopathological findings and the three pre- vious reports ${ }^{1-3}$ further confirm this recently emerging disease. In addition, we present neuropathological features of our patient, which had some similarities to Hallarvorden-Spatz syndrome. ${ }^{10}$

\section{Case report}

The patient was a 58 year old Japanese man with a 13 year history of diabetes mellitus. His wife noticed his depressive mood and forgetfulness; this had appeared insidiously and worsened slowly for two years. Neurological examination showed oral dyskinesia although the rest of the cranial nerve functions were intact. No motor or sensory disturbances were noted. The results of neuropsychiatric examinations were consistent with subcortical dementia: the WAIS full scale was IQ 69 , verbal IQ 80, and performance IQ 62 . Ophthalmological examination disclosed retinal degeneration and there was no KayserFleischer ring in the cornea. Laboratory examination showed serum iron concentration of 16 (normal 90-180) $\mu \mathrm{g} / \mathrm{dl}$, total iron binding capacity 193 (normal $250-390$ ) $\mu \mathrm{g} / \mathrm{dl}$, and ferritin 3200 (normal 80-220) ng/dl. Serum total protein was $6.5 \mathrm{~g} / \mathrm{dl}$ and caeruloplasmin concentration was $<2 \mathrm{mg} / \mathrm{dl}$ (the lowest detectable concentration by immunoassay; normal $18-372 \mathrm{mg} / \mathrm{dl}$ ). Copper concentration was 7 (normal 78-181) $\mu \mathrm{g} / \mathrm{dl}$ in the serum and his 24 hour urinary excretion ranged from $5 \cdot 6$ to $7 \cdot 2$ (normal $4 \cdot 2-33 \cdot 0$ ) $\mu \mathrm{g}$. Plasma glucose concentration was $245 \mathrm{mg} / \mathrm{dl}$ in the fasting state and $468 \mathrm{mg} / \mathrm{dl}$ two hours after $75 \mathrm{~g}$ oral glucose loading, consistent with diabetes mellitus. Haematological examination showed microcytic anaemia (red blood cells $402 \times$ $10^{4} / \mu \mathrm{l}$, haemoglobin $10 \cdot 8 \mathrm{~g} / \mathrm{dl}$, packed cell volume $33.2 \%$, mean carpuscular volume 83 $\left.\mu \mathrm{m}^{3}\right)$ and normal white blood cell and thrombocyte counts. Erythrocyte sedimentation rate, liver and renal function tests, and serum concentrations of sodium, potassium, and calcium were normal. A cranial CT showed a high density of the bilateral putamina and caudate nuclei. The putamen, caudate, and cerebellar dentate nuclei were hypointense on both $\mathrm{T} 1$ and $\mathrm{T} 2$ weighted MRI (figure, $\mathrm{A}$ ).

His five siblings had no physical or neurological abnormalities. Their parents were first cousins who were dead at the time of the family study. Four of the siblings had decreased 


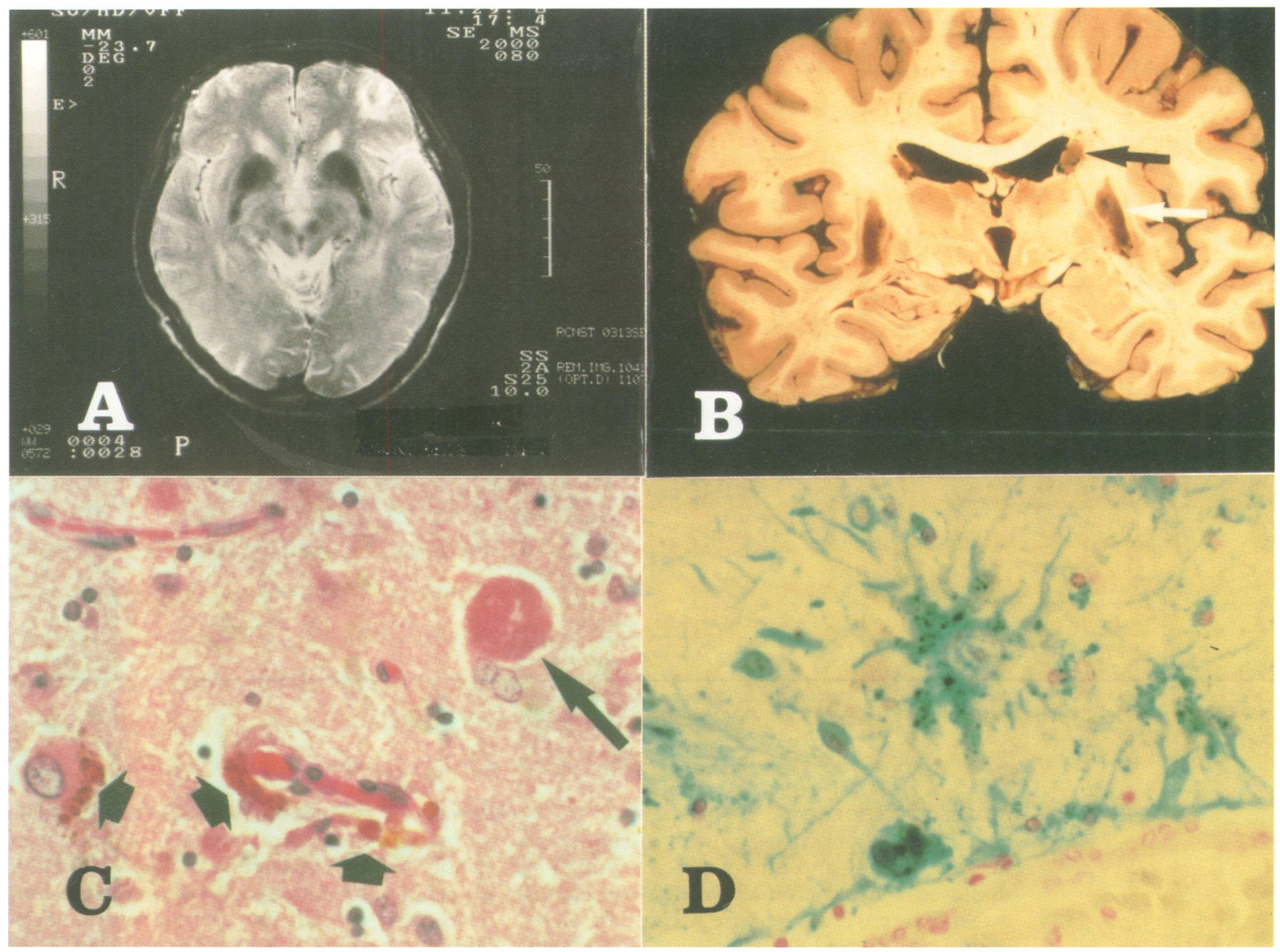

(A) neuroimaging, (B) gross pathological, and (C and D) microscopic features of the brain. (A) T2 weighted MRI of the brain, showing a diffuse loss of signal intensity in the putamen and the caudate nucleus consistent with iron deposition. (B) $A$ coronal section of the brain at the level of the mamillary body: the putamen (white arrow) and the caudate nucleus (black arrow) show red brown discoloration. (C) The caudate nucleus shows neuronal cell loss and reactive astrocytosis. Also found are brown pigments (arrowheads) in astrocytes and perivascular regions. The arrow indicates a spheroid (haematoxylin and eosin stain, originally $\times 860$ ). (D) Perls' stain shows iron deposition in astrocytes and perivascular regions as blue reaction products (the caudate nucleus originally $\times 860$ ).

serum concentrations of caeruloplasmin, which were consistent with heterozygotes of an autosomal recessive phenotype.

The patient was found dead in his home and necropsy was performed 20 hours postmortem. Representative specimens from the brain and the visceral organs were processed for histopathological examination after fixing in $20 \%$ formaldehyde. Several specimens were examined histochemically with Perls' stain for iron and rhodanine and Shikata's stains for copper.

\section{Necropsy results}

\section{NEUROPATHOLOGY}

The brain weighted $1300 \mathrm{~g}$ and appeared normal externally. Macroscopic sections of the brain disclosed symmetric red-brown discoloration in the putamen, caudate nucleus, and cerebellar dentate nucleus (figure, B). Microscopic examination of those regions disclosed neuronal cell loss with reactive astrocytosis and deposition of many pigment granules (figure, C). Those granules yielded a strong reaction with Perls' stain, showing iron deposition in residual neurons, astrocytes, and neu- ropils around blood vessels (figure, D). Eosinophilic, round to oval non-nucleated structures consistent with spheroids were occasionally noted (figure, C). Astrocytosis in those lesions consisted mainly of hypertrophic astrocytes and many of them had iron pigments (figure, D). There were a few Alzheimer type II cells; Opalski cells were not seen. Rhodanine and Shikata's stains for copper did not show any positive results in the above regions. Microscopic examination of other regions of the brain showed mild Purkinje cell loss in the cerebellum and mild to moderate iron deposition in all lobes of the cerebral cortex and cerebellar Purkinje cell layer. There was no apparent neuronal cell loss in the glubus pallidus, substantia nigra, hippocampus, thalamus, and the Meynert nucleus, although there was mild iron deposition. No copper deposition was detectable histochemically in those regions of the brain. Gross and microscopic examination of the brain did not show any cerebrovascular lesions. The main arteries of the brain had no atheromatous thickening. Histopathological examination showed only mild arteriosclerotic changes and the basal ganglia did not show any lacunae or small infarcts. 


\begin{tabular}{|c|c|c|c|c|c|c|c|c|}
\hline \multirow[b]{2}{*}{ Authors } & \multirow{2}{*}{$\begin{array}{l}\text { Patient } \\
\text { age sex }\end{array}$} & \multirow{2}{*}{$\begin{array}{l}\text { Mood of } \\
\text { inheritance }\end{array}$} & \multirow{2}{*}{$\begin{array}{l}\text { Mutation of the } \\
\text { caeruloplasmin gene }\end{array}$} & \multirow{2}{*}{$\begin{array}{l}\text { Neurological } \\
\text { findings }\end{array}$} & \multirow{2}{*}{$\begin{array}{l}\text { Systemic } \\
\text { findings }\end{array}$} & \multicolumn{3}{|c|}{ Laboratory findingst } \\
\hline & & & & & & Caeruloplasmin & Iron & Ferritin \\
\hline \multirow[t]{3}{*}{$\begin{array}{l}\text { Miyajima } \\
\text { et al } \\
(1987)\end{array}$} & $\begin{array}{l}52 \mathrm{~F} \\
(\mathrm{III}-3)^{\star}\end{array}$ & \multirow[t]{3}{*}{$\begin{array}{l}\text { Autosomal } \\
\text { recessive }\end{array}$} & \multirow[t]{3}{*}{ 5-Base pair insertion ${ }^{5}$} & $\begin{array}{l}\text { Blepharospasm, } \\
\text { oral spasm }\end{array}$ & \multirow{2}{*}{$\begin{array}{l}\text { Retinal } \\
\text { degeneration } \\
\text { anaemia } \\
\text { Retinal } \\
\text { degeneration }\end{array}$} & $<0.6$ & 24 & 2100 \\
\hline & $\begin{array}{l}47 \mathrm{~F} \\
\text { (III-5) }\end{array}$ & & & None & & $<0.6$ & 30 & 2000 \\
\hline & $\begin{array}{l}45 \mathrm{M} \\
\text { (III-6) }\end{array}$ & & & None & $\begin{array}{l}\text { Retinal } \\
\text { degeneration }\end{array}$ & $\begin{array}{l}0 \cdot 8 \\
(17-37 \mathrm{mg} / \mathrm{dl})\end{array}$ & $\begin{array}{l}32 \\
(70-150 \mu \mathrm{g} / \mathrm{dl})\end{array}$ & $\begin{array}{l}\text { Not } \\
\text { described } \\
(10-90 \mathrm{ng} / \mathrm{ml})\end{array}$ \\
\hline \multirow[t]{2}{*}{$\begin{array}{l}\text { Logan } \\
\text { et } a l^{2} \\
(1994)\end{array}$} & $\begin{array}{l}58 \mathrm{M} \\
\text { (V8) }\end{array}$ & \multirow[t]{2}{*}{$\begin{array}{l}\text { Autosomal } \\
\text { recessive }\end{array}$} & \multirow[t]{2}{*}{$\begin{array}{l}\text { Unknown }{ }^{2} \\
\text { (linkage to } 3 q 25 \text { ) }\end{array}$} & Dementia & $\begin{array}{l}\text { Diabetes, } \\
\text { retinal } \\
\text { degeneration }\end{array}$ & $<0.02$ & 5 & 1530 \\
\hline & $\begin{array}{l}55 \mathrm{M} \\
(\mathrm{V} 11)\end{array}$ & & & Dementia & Diabetes & $\begin{array}{l}<0.02 \\
(0.21-0.49 \mathrm{~g} / 1)\end{array}$ & $\stackrel{6}{(10-30 \mu \mathrm{mol} / \mathrm{l})}$ & $\begin{array}{l}1224 \\
(15-230 \mu \mathrm{g} / \mathrm{l})\end{array}$ \\
\hline \multirow{4}{*}{$\begin{array}{l}\text { Morita } \\
\text { et al }^{3} \\
\text { (1995) }\end{array}$} & $\begin{array}{l}63 \mathrm{~F} \\
\text { (III-1) }\end{array}$ & \multirow[t]{4}{*}{$\begin{array}{l}\text { Autosomal } \\
\text { recessive }\end{array}$} & \multirow[t]{4}{*}{ Point mutation ${ }^{4}$} & None & $\begin{array}{l}\text { Diabetes, } \\
\text { anaemia }\end{array}$ & $<1$ & 20 & 496 \\
\hline & $\begin{array}{l}55 \mathrm{~F} \ddagger \\
(\text { III-2) }\end{array}$ & & & $\begin{array}{l}\text { Dementia, } \\
\text { ataxia, } \\
\text { torticollis, } \\
\text { grimacing }\end{array}$ & $\begin{array}{l}\text { Diabetes, } \\
\text { retinal } \\
\text { degeneration }\end{array}$ & $<1$ & 27 & 787 \\
\hline & $\begin{array}{l}50 \mathrm{~F} \\
(\mathrm{III}-5)\end{array}$ & & & $\begin{array}{l}\text { Dementia, } \\
\text { oral dyskinesia, } \\
\text { ataxia }\end{array}$ & $\begin{array}{l}\text { Diabetes } \\
\text { retinal } \\
\text { degeneration }\end{array}$ & $<1$ & 43 & 1322 \\
\hline & $\begin{array}{l}40 \mathrm{M} \\
\text { (III-8) }\end{array}$ & & & $\begin{array}{l}\text { Facial tic, } \\
\text { ataxia }\end{array}$ & $\begin{array}{l}\text { Diabetes, } \\
\text { retinal } \\
\text { degeneration }\end{array}$ & $\begin{array}{l}<1 \\
(20-40 \mathrm{mg} / \mathrm{dl})\end{array}$ & $\begin{array}{l}35 \\
(\mathrm{M} 44-192 \mu \mathrm{g} / \mathrm{dl}) \\
(\mathrm{F} 29-164 \mu / \mathrm{dl})\end{array}$ & $\begin{array}{l}834 \\
(\mathrm{M} 25-280 \mathrm{ng} / \mathrm{ml}) \\
(\mathrm{F} 10-120 \mathrm{ng} / \mathrm{ml})\end{array}$ \\
\hline Our case & $58 \mathrm{M} \ddagger$ & $\begin{array}{l}\text { Autosomal } \\
\text { recessive }\end{array}$ & Point mutation ${ }^{9}$ & $\begin{array}{l}\text { Dementia, } \\
\text { oral dyskinesia }\end{array}$ & $\begin{array}{l}\text { Diabetes, } \\
\text { retinal } \\
\text { degeneration, } \\
\text { anaemia }\end{array}$ & $\begin{array}{l}<2 \\
(18-37 \mathrm{mg} / \mathrm{dl})\end{array}$ & $\begin{array}{l}16 \\
(90-180 \mu \mathrm{g} / \mathrm{dl})\end{array}$ & $\begin{array}{l}3200 \\
(80-220 \mathrm{ng} / \mathrm{ml})\end{array}$ \\
\hline
\end{tabular}

^Numbers in parentheses $=$ pedigree numbers in the original articles, indicating that they are brothers or sisters.

fUnits and normal ranges of measurements from the original papers are indicated in parentheses.

GENERAL PATHOLOGY

The liver showed a brown discoloration macroscopically and microscopic examination disclosed a heavy iron deposition in hepatocytes. There were otherwise no specific alterations such as cirrhotic changes. Other organs had microscopic iron deposition of varying degrees. The pancreas, kidney, and heart showed moderate to severe iron deposition, and the spleen, bone marrow, thyroid gland, and pituitary gland had mild iron deposition.

\section{Discussion}

The patient presented here and the other recorded patients ${ }^{1-3}$ represent a specific disorder characterised by serum caeruloplasmin deficiency. Although Wilson's disease shows a decrease in serum caeruloplasmin, it can be ruled out by the mutations of the caeruloplasmin gene in those patients (table), which is different from the Wilson's disease gene. ${ }^{611}$ The differences in clinical presentations are that the patients did not have Kayser-Fleischer rings, liver cirrhosis, or increased urinary copper excretion. Furthermore, our patient showed iron deposition in the brain and liver instead of copper accumulation. Patients with hereditary hypocaeruloplasminaemia, ${ }^{1213}$ which was first reported by Cox, ${ }^{12}$ showed decreased serum caeruloplasmin concentrations in affected members of the family but the members were reported to have no medical problems. ${ }^{12}{ }^{13}$ It is uncertain whether they are heterozygotes for hereditary caeruloplasmin deficiency, because there are no chance matings of members with hypocaeruloplasminaemia from those families. ${ }^{13}$

The common features of the patients are familial caeruloplasmin deficiency and iron deposition in the brain and liver. Caeruloplasmin's role in iron metabolism has been established in animal studies ${ }^{14}$ and Miyajima et $a l^{1}$ proposed a pathomechanism of tissue iron deposition caused by caeruloplasmin deficiency in humans. Caeruloplasmin is a copper containing protein with ferroxidase activity that oxidises ferrous iron (Fe (II)) to ferric iron (Fe (III)).${ }^{15}$ Because Fe III is the only iron form that can bind to apotransferrin and enter the bloodstream, caeruloplasmin deficiency would decrease recycling of iron from cell to plasma, resulting in cellular iron deposition. ${ }^{1}$ Laboratory findings for the recorded patients and ours (table) show decreased iron but greatly increased ferritin concentrations in the serum that could be due to caeruloplasmin deficiency.

The present pathological findings correlate well with the clinical features of the other recorded patients and our patient (table). Iron deposition and neuronal cell loss in the putamen and caudate nucleus can explain subcortical dementia ${ }^{23}$ and involuntary movements such as blepharospasm. ${ }^{1}$ Cerebellar Purkinje cell loss and the dentate nucleus lesion could result in cerebellar symptoms. ${ }^{3}$ Diabetes mellitus $^{23}$ could be due to increased iron in the pancreas, resulting in impaired insulin secretion. ${ }^{16}$ The brain MRI findings can be explained by massive iron deposition to the cerebral basal ganglia and cerebellar dentate nucleus. ${ }^{17}$ The variation in clinical findings among the reported patients ${ }^{1-3}$ and the present one could be explained partly by the differences in the severity of iron deposition and subsequent tissue damage in affected organs of the body. Other factors such as differences in the mutations of the caeruloplasmin gene among the reported families ${ }^{49}$ could con- 
tribute to the variation of clinical presentations.

Striking features of the neuropathological changes in affected areas of our patient were neuronal cell loss, iron deposition, and spheroid formation, similar to those in Hallervorden-Spatz syndrome. ${ }^{10} 11$ The combination of iron deposition and spheroids in the same lesion had previously been considered unique to Hallervorden-Spatz syndrome. ${ }^{11}$ The distinction between our patient and patients with Hallervorden-Spatz syndrome is that our patient did not show severe pathological changes in the glubus pallidus and substantia nigra, and changes in those regions are the pathological hallmark of Hallervorden-Spatz syndrome. ${ }^{1011}$ It remains unexplained why similar histological changes occur in different areas of the brain in these different disorders. One hypothesis is that a metabolic block in recycling of cellular iron would produce similar pathological responses in the brain. In our patient, decreased ferroxidase activity due to caeruloplasmin deficiency could impair iron recycling in the brain and in HallervordenSpatz disease, ${ }^{18}$ decreased cysteine dioxygenase activity has been proposed to cause iron accumulation in the globus pallidus. Variations among metabolic blocks in recycling of iron would determine selective vulnerability of brain regions and subsequent specific neurological abnormalities.

In conclusion, our patient and other patients reported ${ }^{1-3}$ constitute a clinicopathological disease entity of hereditary caeruloplasmin deficiency which shows clinical symptoms such as dementia, involuntary movements, and diabetes mellitus, and pathological iron deposition in the brain, liver, pancreas, and other organs. We propose the existence of a group of disorders caused by a metabolic defect in cellular recycling of iron in the brain. This includes hereditary caeruloplasmin deficiency and Hallervorden-Spatz syndrome, and these are different from diseases caused by iron overload, such as hereditary haemochromatosis. ${ }^{8}$

1 Miyajima $H$, Nishimura $Y$, Mizoguchi K, Sakamoto $M$, Shimizu T, Honda N. Familial apoceruloplasmin deficiency associated with blepharospasm and retinal degenciency associated with blepharosp

2 Logan JI, Harveyson KB, Wisdom GB, Hughes AE, Archbold GPR. Hereditary ceruloplasmin deficiency, dementia and diabetes mellitus. $Q$ f Med 1994;87: 663-70.

3 Morita $\mathrm{H}$, Ikeda S, Yamamoto $\mathrm{K}$, et al. Hereditary ceruloplasmin deficiency with hemosiderosis: a clinicopathological study of a Japanese family. Ann Neurol 1995;37: 646-56.

4 Yoshida K, Furihata K, Takeda S, et al. A mutation in the ceruloplasmin gene is associated with systemic hemosiderosis in humans. Nature Genetics 1995;9:267-72.

5 Harris ZL, Takahashi Y, Miyajima H, Serizawa M, Mac Gillivray RTA, Gitlin JD. Aceruloplasminemia: molecular characterization of this disorder of iron metabolism. Proc Natl Acad Sci USA 1995;92:2539-43.

6 Chelly J, Monaco AP. Cloning the Wilson disease gene. Nature Genetics 1993;5:317-8.

7 Edwards CQ. Hemochromatosis and other iron storage disorders. In: Lee GR, Bithell TC, Foerster J, Athers JW Lukens JN, eds. Witnrobe's clinical hematology, 9th ed. Philadelphia: Lea and Febiger, 1993:872-84.

8 Nielsen JE, Jensen NL, Krabbe K. Hereditary haemochromatosis: a case of iron accumulation in the basal ganglia associated with a parkinsonian syndrome. $f$ Neurol Neurosurg Psychiatry 1995;59:318-21.

9 Daimon M, Kato T, Kawanami T, et al. A nonsense mutation of the ceruloplasmin gene in hereditary ceruloplasmin deficiency with diabetes mellitus. Biochem Biophys Res Commun 1995;217:89-95.

10 Swaiman KF. Hallervorden-Spatz syndrome and brain iron metabolism. Arch Neurol 1991;48:1285-93.

11 Duchen LW, Jacobs JM. Nutritional deficiencies and metabolic disorders. In: Adams JH, Duchen LW, eds. Greenfield's neuropathology. 5th ed. London: Edward Arnold, 1992:811-80.

12 Cox DW. Factors influencing ceruloplasmin levels in normal individuals. F Lab Clin Med 1966;68:893-904.

13 Edwards CQ, Williams DM, Cartwright GE. Hereditary hypoceruloplasminemia. Clin Genet 1979;15:311-6.

14 Osaki S, Johnson DA, Frieden E. The mobilization of iron from the perfused mammalian liver by a serum coppe enzyme, ferroxidase I. $¥$ Biol Chem 1971;246:3018-23.

15 Osaki S, Johnson DA, Frieden E. The possible significance of the ferrous oxidase activity of ceruloplasmin in normal human serum. F Biol Chem 1966;241:2746-51.

16 Dymock IW, Cassaar J, Pyke DA, Oakley WG, Williams R Observations on the pathogenesis, complications, and Observations on the pathogenesis, complications, and treatment of diabetes in 115

17 Drayer B, Burger P, Darwin R, Johnson GA. Magnetic resonance imaging of brain iron. AfNR Am $¥$ Neuroradiol onance imaging

18 Perry TL, Norman MG, Yong VW, et al. HallervordenSpatz disease: cysteine accumulation and cysteine dioxygenase deficiency in the globus pallidus. Ann Neuro 1985;18:482-9. 